\title{
Assessment of the effect of punch full-thickness skin grafting on wound epithelialization
}

\section{Ocena wpływu mikroprzeszczepów skóry pełnej grubości wykonywanych sztancą na epitelializację łożyska rany}

Marcela A. Nowak, Dorota M. Mehrholz, Wioletta Barańska-Rybak

Department of Dermatology, Venereology and Allergology, Medical University of Gdansk, Gdansk, Poland

Katedra i Klinika Dermatologii, Wenerologii i Alergologii, Gdański Uniwersytet Medyczny, Gdańsk, Polska

Dermatol Rev/Przegl Dermatol 2021, 108, 266-274

DOI: https://doi.org//0.5 | |4/dr.2021.1 10785

ADDRESS FOR CORRESPONDENCE/
AUTOR DO KORESPONDENCJI:
lek. Marcela A. Nowak
Klinika Dermatologii,
Wenerologii i Alergologii
Gdański Uniwersytet Medyczny
Gdańsk, Polska
tel.: +48 606908780
e-mail: mcela94@gmail.com

\section{ABSTRACT}

Introduction: One of the methods to accelerate skin epithelialisation is skin grafting. Various methods of skin transplantations are available, such as full thickness skin transplantation, intermediate-thickness skin transplant using a dermatome, and epidermal islet transplantation using vacuum apparatus an epidermal harvesting system. These methods, however, require the use of specialised and expensive equipment. An alternative is to perform full-thickness skin grafts with a dermatological punch.

Objective: The aim of the study was to utilize the new technique of punch grafting and evaluate it's effect on wound healing.

Material and methods: Five patients with granulating venous ulcers, which were not infected or cancerous, underwent the procedure. Full thickness punch grafts were placed every $2 \mathrm{~cm}^{2}$. Patients were followed up every week for 3 months and assessed for the number of micrografts rejected and percentage of the wound that has epithelialised. We have also noted the VAS pain scale.

Results: Reduction in the wound area after 30 days was observed in all patients. In 2 patients, complete resolution was observed. No adverse effects were recorded. Average visual analogue scale (1-10) for pain was $4.4 \pm 0.927$. The procedure took on average $39 \pm 4.3$ minutes.

Conclusions: Micrografts have a very high potential to accelerate the epithelialisation of chronic ulcers. Compared to the conventional procedures, they are costeffective and easier to perform. It is an effective method that can be used in outpatient settings.

Key words: chronic wounds, ulcers, skin grafting, epithelialisation.

\section{STRESZCZENIE}

Wprowadzenie: Jedną z metod przyspieszania procesu epitelializacji skóry są przeszczepy skórne. Dostępne są różne techniki przeszczepiania skóry. Należą do nich: przeszczep skóry pełnej grubości, przeszczep skóry pośredniej grubości przy zastosowaniu dermatomu oraz przeszczep punktowy wysepek naskórka przy wykorzystaniu aparatu próżniowego. Metody te wymagają jednak specjalistycznego sprzętu. Metodą alternatywną jest przeszczep skóry pełnej grubości wykonywany za pomocą sztancy dermatologicznej. 
Cel pracy: W niniejszej pracy przedstawiamy metodę przeszczepu skóry oraz efekty zabiegu.

Materiał i metody: Zabiegowi poddano 5 pacjentów z ziarninującymi owrzodzeniami żylnymi bez cech zakażenia lub nowotworzenia. Za pomocą sztancy $5 \mathrm{~mm}$ wykonywano 1 mikroprzeszczep skóry na każde $2 \mathrm{~cm}^{2}$. Co tydzień przez 3 miesiące u pacjentów przeprowadzono badanie kontrolne, aby określić liczbę odrzuconych mikroprzeszczepów oraz ocenić procentowo powierzchnię rany, która uległa epitelializacji. Dokonano również oceny natężenia bólu związanego z zabiegiem na podstawie skali wzrokowo-analogowej (VAS).

Wyniki: Po 30 dniach u wszystkich pacjentów zaobserwowano zmniejszenie powierzchni rany. U 2 pacjentów stwierdzono całkowite ustąpienie zmian. Nie zgłoszono żadnych działań niepożądanych. Średni wynik natężenia bólu w skali VAS (1-10) wyniósł 4,4 $\pm 0,927$. Zabieg trwał średnio $39 \pm 4,3$ minuty.

Wnioski: Mikroprzeszczepy skóry mają ogromny potencjał pod względem przyspieszania procesu epitelializacji u chorych z przewlekłymi owrzodzeniami. W porównaniu z zabiegami tradycyjnymi jest to metoda tańsza i prostsza. Można ją stosować z dobrym skutkiem w warunkach ambulatoryjnych.

Słowa kluczowe: rany przewlekłe, owrzodzenia, przeszczepy skóry, epitelializacja.

\section{INTRODUCTION}

Chronic venous ulcers are an end stage of chronic venous insufficiency [1]. Chronic venous insufficiency is caused by impaired venous valves that lead to venous stasis. This therefore promotes venous ulceration, which does not heal properly due to constant disturbances in the venous system. For this reason, all of the patients are subjected to compression therapy (stockings or bandage compression), which prevents backflow of blood and venous stasis [2-5].

Moreover, TIMERS [T (tissue), I (inflammation/infection), M (moisture), E (edge), R (regeneration), S (social factors)]strategy, which includes comprehensive preparation of the wound bed with debridement, control of infection, selection of optimal dressing and putting patient's satisfaction as first, is a key to the proper healing of venous ulcers [6-11].

Chronic venous insufficiency is a growing problem for modern society, due to its higher prevalence and risk factors, such as older age, female gender, obesity, positive family history and sedentary lifestyle [12-15]. It stands for huge costs of both medical supplies as dressings and medical help [16].

The final part of wound healing is epithelialisation, which stands for a complete closure of the wound. In most cases, this stage is significantly prolonged due to disorders of the skin structure. As mentioned be-

\section{WPROWADZENIE}

Przewlekłe owrzodzenia żylne uznawane są za najbardziej zaawansowane stadium przewlekłej niewydolności żylnej [1]. Przewlekła niewydolność żylna jest stanem wywoływanym niewydolnością zastawek żylnych, który prowadzi do zastoju krwi w układzie żylnym. Sprzyja on powstawaniu owrzodzeń, które nie goją się prawidłowo ze względu na stałe utrzymywanie się zaburzeń żylnych. Z tego względu wszyscy pacjenci poddawani są kompresjoterapii (przy wykorzystaniu pończoch uciskowych lub bandaży kompresyjnych), która zapobiega cofaniu się krwi i powstawaniu zastoju żylnego [2-5].

Kluczem do prawidłowego gojenia owrzodzeń żylnych jest strategia leczenia ran TIMERS [T (tissue), I (inflammation/infection), M (moisture), E (edge), $\mathrm{R}$ (regeneration), S (social factors)], która obejmuje dokładne oczyszczenie i opracowanie tkanek w łożysku rany, kontrolę infekcji i dobór optymalnego opatrunku oraz priorytetowe traktowanie dobra pacjenta [6-11].

Przewlekłe owrzodzenie żylne stanowi coraz większy problem we współczesnych społeczeństwach ze względu na wzrost częstości występowania i czynniki ryzyka (podeszły wiek, płeć żeńska, otyłość, dodatni wywiad rodzinny oraz siedzący tryb życia) [12-15]. Leczenie przewlekłego owrzodzenia żylnego wiąże się z ogromnymi kosztami, które obejmują zarówno środki medyczne (m.in. opatrunki), jak i pomoc lekarską [16]. 
fore, chronic venous insufficiency inevitably disrupts skin healing and regeneration processes [17]. Not only is the skin more susceptible to new injuries, yet it is also less prone to restore its basal structure. For those reasons, skin transplant is performed in many cases of clean, non-infected wounds to accelerate the wound closure. This procedure significantly shortens the healing time, although in Poland it is only reserved for hospitalized patients. It is popular to use a dermatome or specialized equipment for collecting islands of the epidermis [18-24]. Those methods, however, need to be performed by qualified surgeons in a surgical room.

There is a method described on the basis of single cases in which a dermatological punch is used to collect the skin [25-27]. It is a cheaper method compared to a dermatome or epidermal transplant and easier to use. However, there is a lack of more research on this topic. What makes our study unique is that, knowing the pathomechanism of chronic venous insufficiency and principles to its causal treatment, we have included compression therapy as part of the treatment. Not only is it important for preventing the back flow of venous blood, yet it is also crucial for better acceptance of the graft and hence epithelialisation of the ulcer. No compression therapy was used in the studies that have already been published, which could have prolonged the healing time of the ulcer $[25,26]$.

\section{MATERIAL AND METHODS}

The project involved conducting an observational study on the effectiveness of micrografts using a dermatological punch to accelerate the epidermal ulcer epithelialisation. The study was conducted on 5 patients. Patients' data were encrypted in accordance with the Personal Data Protection Act. After reading the written information about the purpose and method of conducting the study, obtaining comprehensive answers to the questions asked and after signing the written consent to participate in the study, the patient, who met the inclusion and exclusion criteria (table 1) was qualified for the study.

We have received an approval of the Independent Bioethics Commission for Research at the Medical University of Gdansk to conduct our research (NKBBN/601/2019).

The primary endpoint of our study was the degree of wound epithelialization, measured by calculating relative wound epithelialisation $=$ (wound area at day $0-$ wound area at day 30 )/ wound area at day $0 \times$ $100 \%$.

Assessment of the ulcer size using a specially prepared $0.5 \mathrm{~cm}$ film and photographic documentation was carried out on the day of the procedure, as well as $3,7,14$ and 30 days after the procedure. The sur-
Ostatnią fazą gojenia rany jest epitelializacja, w której następuje zamknięcie rany. W większości przypadków etap ten znamiennie się wydłuża z powodu zaburzeń w strukturze skóry. Jak wspomniano wyżej, przewlekłe owrzodzenie żylne nieuchronnie prowadzi do zaburzeń w procesie gojenia i regeneracji skóry [17]. Oprócz zwiększenia podatności skóry na powstawanie nowych urazów, upośledzeniu ulega jej zdolność odbudowy podstawowej struktury. Z tego względu w wielu przypadkach czystych ran bez cech zakażenia wykonywany jest przeszczep skóry, aby przyspieszyć proces zamykania się rany. Zabieg ten znamiennie skraca czas gojenia, choć w Polsce wykonywany jest wyłącznie u pacjentów hospitalizowanych. Powszechnie wykorzystuje się dermatom lub wyspecjalizowane urządzenia do pobierania wysepek naskórka [18-24]. Zabiegi te muszą być jednak wykonywane przez wykwalifikowanych chirurgów w warunkach sali operacyjnej.

Dostępna jest również opisana na podstawie pojedynczych przypadków metoda, w której do pobierania skóry do przeszczepu wykorzystywana jest sztanca dermatologiczna [25-27]. Jest to metoda prostsza oraz tańsza w porównaniu z przeszczepami dermatomowymi i przeszczepami punktowymi wykonywanymi przy zastosowaniu systemu próżniowego. Niezbędne są jednak dalsze badania w tym zakresie. Szczególną cechą naszego badania opisywanego w tej pracy jest włączenie kompresjoterapii jako elementu leczenia. Terapia uciskowa zapobiega wstecznemu przepływowi krwi żylnej, a ponadto sprzyja przyjęciu się przeszczepu, co pobudza proces epitelializacji owrzodzenia. W pracach dostępnych w piśmiennictwie nie stosowano terapii uciskowej, co mogło wpływać na wydłużenie czasu gojenia owrzodzeń $[25,26]$.

\section{MATERIAŁ I METODY}

Przeprowadzono badanie obserwacyjne, w którym analizowano skuteczność mikroprzeszczepów wykonywanych przy użyciu sztancy dermatologicznej w przyspieszaniu epitelializacji owrzodzeń naskórka. Badaniem objęto grupę złożoną z 5 pacjentów. Dane uczestników poddano anonimizacji zgodnie z obowiązującą Ustawą o ochronie danych osobowych. Pacjenci spełniający kryteria włączenia i wyłączenia (tab. 1) byli kwalifikowani do udziału w badaniu po zapoznaniu się z pisemną informacją o celu i procedurze przeprowadzenia badania, uzyskaniu odpowiedzi na ewentualne pytania oraz podpisaniu formularza świadomej zgody na udział.

Przed przeprowadzeniem badania uzyskano zgodę Niezależnej Komisji Bioetycznej ds. Badań Naukowych przy Gdańskim Uniwersytecie Medycznym (NKBBN/601/2019).

Pierwszorzędowym punktem końcowym badania był stopień epitelializacji rany określany przez obliczenie względnego stopnia epitelializacji rany = 
Table I. Inclusion and exclusion criteria

Tabela I. Kryteria włączenia i wyłączenia

\section{Inclusion criteria/Kryteria włączenia}

Chronic venous leg ulceration lasting at least 3 months before start of treatment/Przewlekłe owrzodzenie żylne kończyn dolnych utrzymujące się przez co najmniej 3 miesiące przed rozpoczęciem leczenia

Age $>18$ years and $<90$ years Wiek $>18$ lat $\mathrm{i}<90$ lat

\section{Exclusion criteria/Kryteria wyłączenia}

Ulceration of a different aetiology than venous/Owrzodzenie o etiologii innej niż żylna
A fragment of the ulcer with a maximum surface area of $60 \mathrm{~cm}^{2} /$ Fragment owrzodzenia o maksymalnej powierzchni $60 \mathrm{~cm}^{2}$ Ulceration without fistula/Owrzodzenie bez przetoki
Presence of signs of systemic infection (fever, acute abscess, subcutaneous tissue inflammation, leucocytosis, elevated CRP)/ Obecność objawów zakażenia ogólnoustrojowego (gorączka, ostry ropień, zapalenie tkanki podskórnej, leukocytoza, podwyższony poziom CRP)

Presence of signs of infection in the wound/Obecność cech zakażenia w obrębie rany

Use of immunosuppressive drugs within 30 days before the start of the study/Przyjmowanie leków immunosupresyjnych w czasie 30 dni poprzedzających rozpoczęcie badania

No signs of infection in the wound and systemic infection/Brak cech zakażenia rany i zakażenia ogólnoustrojowego
Hypersensitivity to any component of the tested product/ Nadwrażliwość na dowolny składnik badanego produktu

Ulceration covered with necrosis/Owrzodzenie pokryte martwica

\begin{tabular}{l}
\hline Pregnancy and breastfeeding/Ciąża i karmienie piersią \\
\hline Poorly controlled diabetes/Nieprawidłowo kontrolowana \\
cukrzyca \\
\hline Immune disorders/Zaburzenia immunologiczne \\
\hline Active cancer/Aktywny nowotwór \\
\hline Connective tissue diseases during remission/Choroby tkanki \\
łącznej w okresie remisji \\
Malnutrition/Niedożywienie \\
Alcoholism, nicotinism or drug addiction/Alkoholizm, nikotynizm \\
lub uzależnienie od narkotyków \\
\hline Lack of cooperation on the part of the patient/Brak współpracy \\
ze strony pacjenta \\
\hline Participation in any other study during the 30 days preceding \\
the study/Udział w innym badaniu w okresie 30 dni \\
poprzedzających to badanie
\end{tabular}

face area of the ulcer was measured using planimetry (tab. 1).

\section{Procedure}

Donor sites (skin of thighs) was anaesthetized using infiltration injection of Lignocainum hydrochloricum 1\%. Recipient sites were anaesthetized using Lignocainum $2 \%$ gel under occlusive bandage for 30 minutes. Debridement of the recipient sites with Volkmann spoon was performed. Grafts were taken with the use of a $5 \mathrm{~mm}$ diameter skin punch (for every $2 \mathrm{~cm}^{2}$ of the recipient site, one graft will be placed) from the donor site. Recipient sites were prepared with another skin punch. Skin grafts were placed into the recipient sites after performing local haemostasis with sterile gauze. Mesh dressing with silver (Physiotulle ${ }^{\circledR}$ Ag) as a primary dressing and non-adhesive polyurethane foam dressing (Biatain Non-Adhesive ${ }^{\circledR}$ ) as a second- (powierzchnia rany $\mathrm{w}$ dniu 0 - powierzchnia rany $\mathrm{w}$ dniu 30.)/powierzchnia rany $\mathrm{w}$ dniu $0 \times 100 \%$.

Ocenę wielkości owrzodzenia za pomocą specjalnie przygotowanej folii $0,5 \mathrm{~cm}$ oraz dokumentację fotograficzną wykonywano w dniu zabiegu, a także po 3, 7, 14 i 30 dniach od zabiegu. Pomiar powierzchni owrzodzenia przeprowadzono metodą planimetryczną.

\section{Procedura}

W miejscach dawczych (skóra na udach) zastosowano znieczulenie nasiękowe poprzez wstrzyknięcie Lignocainum hydrochloricum 1\%. Miejsca biorcze znieczulono, aplikując żel Lignocainum $2 \%$ pod opatrunkiem okluzyjnym (30 minut). Miejsca biorcze oczyszczono łyżeczką dermatologiczną typu Volkmann. Mikroprzeszczepy pobierano z miejsca dawczego za pomocą sztancy dermatologicznej o średnicy $5 \mathrm{~mm}$ (jeden mikroprzeszczep na każde $2 \mathrm{~cm}^{2}$ powierzchni miejsca biorczego). Przy użyciu 
ary dressing was used for the first and every dressing change thereafter. It is important to place mesh dressing first as it prevents adhesion of the graft to the dressing, so the dressings can be changed with no threat to the graft $[28,29]$. At last compression therapy with short stretch bandages was applied to restore physiological blood flow.

\section{Statistical analysis}

General group characteristics and clinical signs at study entry were assessed using descriptive statistical analysis using Statistica 13.3 programme.

The degree of epithelialisation for the group was compared and tested for statistical significance using the Pearson's $\chi^{2}$ test, assuming a significance level of 0.05 .

\section{RESULTS}

The average numbers of grafts placed on the donor site was $5.6 \pm 0.980$ (mean +/- SD) (table 2). The whole procedure lasted on average $39 \pm 4.301$ minutes. Average visual analogue scale (VAS) value of the procedure was $4.4 \pm 0.927$. On average $93 \pm 4.899$ of the grafts were innej sztancy dermatologicznej przygotowywano miejsca biorcze przeszczepów. Przeszczepy skórne umieszczano w miejscach biorczych po uzyskaniu miejscowej hemostazy przy wykorzystaniu sterylnej gazy. Miejsca przeszczepów zaopatrywano opatrunkiem siatkowym ze srebrem (opatrunek pierwotny) oraz bezklejowym opatrunkiem z pianki poliuretanowej (opatrunek wtórny). Te same materiały stosowano przy każdej kolejnej zmianie opatrunku. Zaleca się w pierwszej kolejności nakładać opatrunek siatkowy, ponieważ zapobiega on przyleganiu przeszczepu do opatrunku. Dzięki temu opatrunek może być zmieniany bez zagrożenia dla przeszczepu [28, 29]. Na koniec zabiegu stosowano terapię uciskową przy wykorzystaniu bandaży kompresyjnych o krótkim naciągu, aby przywrócić fizjologiczny przepływ krwi.

\section{Analiza statystyczna}

Ogólną charakterystykę grupy badanej oraz objawy kliniczne na początku badania oceniono za pomocą statystycznej analizy opisowej w programie Statistica 13.3.

Stopień epitelializacji u pacjentów z badanej grupy porównano i oceniono pod kątem istotności sta-

Table 2. Wound area status among the study group at day 0,7 and 30 and the degree of wound epithelialisation, as well as time of the procedure and pain scale

Tabela 2. Powierzchnia rany w grupie badanej w dniu 0, 7. i 30. po zabiegu, stopień epitelializacji rany, czas trwania zabiegu i wynik w skali oceny bólu VAS

\begin{tabular}{|c|c|c|c|c|c|c|c|}
\hline $\begin{array}{l}\text { Patient no./ } \\
\text { Nr pacjenta }\end{array}$ & $\begin{array}{c}\text { Wound area } \\
\text { at day 0/ } \\
\text { Powierzchnia } \\
\text { rany w dniu } 0 \\
{\left[\mathrm{~cm}^{2}\right]^{*}}\end{array}$ & $\begin{array}{l}\text { Time of the } \\
\text { procedure/ } \\
\text { Czas trwania } \\
\text { zabiegu } \\
\text { [min] }\end{array}$ & $\begin{array}{c}\text { VAS scale } \\
\text { value/ } \\
\text { Wartość } \\
\text { w skali VAS } \\
(I-I 0)^{* *}\end{array}$ & $\begin{array}{l}\text { Wound area } \\
\text { at day } 7 / \\
\text { Powierzchnia } \\
\text { rany w dniu } \\
\text { 7. po zabiegu } \\
{\left[\mathrm{cm}^{2}\right]^{*}}\end{array}$ & $\begin{array}{c}\text { Percentage of } \\
\text { grafts accepted } \\
\text { at day } 7 / \text { Odsetek } \\
\text { przyjętych } \\
\text { przeszczepów } \\
\text { w dniu 7. (\%) }\end{array}$ & $\begin{array}{c}\text { Wound area } \\
\text { at day } 30 / \\
\text { Powierzchnia } \\
\text { rany w dniu } \\
\text { 30. po zabiegu } \\
{\left[\mathrm{cm}^{2}\right]^{*}}\end{array}$ & $\begin{array}{l}\text { Degree of wound } \\
\text { epithelialisation at } \\
\text { day } 30 * * * / S t o p i e n ́ \\
\text { epitelializacji rany } \\
\text { w dniu } 30 \text {. po } \\
\text { zabiegu*** (\%) }\end{array}$ \\
\hline I & $|3.65|$ & 35 & 3 & | I.680 & 100 & 0.000 & 100 \\
\hline 2 & 5.131 & 30 & 2 & 4.730 & 75 & 2.702 & 47.339 \\
\hline 3 & 51.431 & 55 & 4 & 37.339 & 90 & 21.802 & 57.609 \\
\hline 4 & 6.728 & 35 & 7 & 3.223 & 100 & 0.000 & 100 \\
\hline 5 & 9.394 & 40 & 6 & 8.285 & 100 & 3.155 & 66.415 \\
\hline $\begin{array}{l}\text { Mean } \pm \\
\text { standard } \\
\text { error/średnia } \\
\pm \text { odchylenie } \\
\text { standardowe }\end{array}$ & $\begin{array}{r}17.267 \\
\pm 8.662\end{array}$ & $39 \pm 4.301$ & $4.4 \pm 0.927$ & $\begin{array}{l}|3.05| \\
\pm 6.246\end{array}$ & $93 \pm 4.899$ & $5.531 \pm 4.120$ & $74.272 \pm 10.928$ \\
\hline $\begin{array}{l}\text { Confidence } \\
\text { level (95\%)/ } \\
\text { Przedział uf- } \\
\text { ności (95\%) }\end{array}$ & - & 11.942 & 2.574 & - & 13.602 & - & 30.342 \\
\hline
\end{tabular}


accepted on day 7 , whereas in 3 patients all the grafts were adopted.

On average, $74.272 \pm 10.928 \%$ of the area of wound at day 0 has epithelialized at day 30. Moreover, in 2 patient complete closure of the wound was observed after 30 days (table 2, figs. 1-3). No adverse effects were recorded.

As our results met the normal distribution, and our $\mathrm{p}$ calculated by Pearson's $\chi^{2}$ test was 0.322 , and therefore is greater than 0.05 , we accept that our results are significant, and do not differ by chance. The observed distribution is therefore not the same as in patients with chronic ulcers, who are treated conservatively.

\section{DISCUSSION}

The experience of the Dermatology Clinic allows us to deduce that micrografts with the help of the skin punch have a very high potential to accelerate the epithelialisation of the venous ulcers. Compared to the procedure performed with the help of an epidermal harvesting system and dermatome, they are cheaper and easier to perform. The cost of one procedure is approximately EUR 10 and includes two skin punches and the suturing kit. In comparison, a dermatome or a epidermal harvesting system procedure costs approximately EUR 1000. This method can shorten wound healing and accelerate epithelialization, without the need to hospitalise the patient before and after the procedure. It can significantly lower the expenses of wound treatment among the patients with chronic ulcers, which are becoming a growing problem for all physicians across the Europe, especially within dermatology wards.

As with every method, where tissue integrity is compromised, there is a possibility of bleeding, infec-

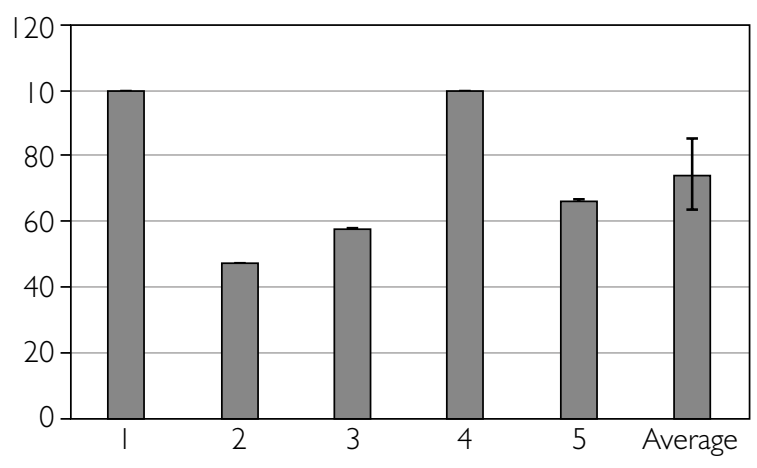

Figure I. Degree of relative wound epithelialisation after 30 days in 5 patients and average value

Rycina I. Stopień względnej epitelializacji rany po 30 dniach u 5 pacjentów i wartość średnia

tystycznej przy użyciu testu $\chi^{2}$ Pearsona, przyjmując poziom istotności statystycznej jako 0,05.

\section{WYNIKI}

Średnia liczba przeszczepów umieszczonych w miejscu dawczym wynosiła 5,6 $\pm 0,980$ (średnia \pm SD). Zabieg trwał średnio $39 \pm 4,3$ minuty. Średnia wartość wizualnej skali analogowej (visual analogue scale - VAS) dla zabiegu wyniosła 4,4 $\pm 0,927$. W 7. dniu przyjęło się średnio $93 \pm 4,899$ przeszczepu, przy czym u 3 pacjentów stwierdzono przyjęcie się wszystkich przeszczepów.

Średnio $74,272 \pm 10,928 \%$ powierzchni rany uległo epitelializacji w 30. dniu $\mathrm{w}$ porównaniu $\mathrm{z}$ dniem 0 . Ponadto u 2 pacjentów po 30 dniach stwierdzono całkowite zamknięcie rany (tab. 2, ryc. 1-3). Nie zgłoszono żadnych działań niepożądanych.

Ponieważ uzyskane wyniki spełniały warunki rozkładu normalnego, a wartość $p$ obliczona przy wy-
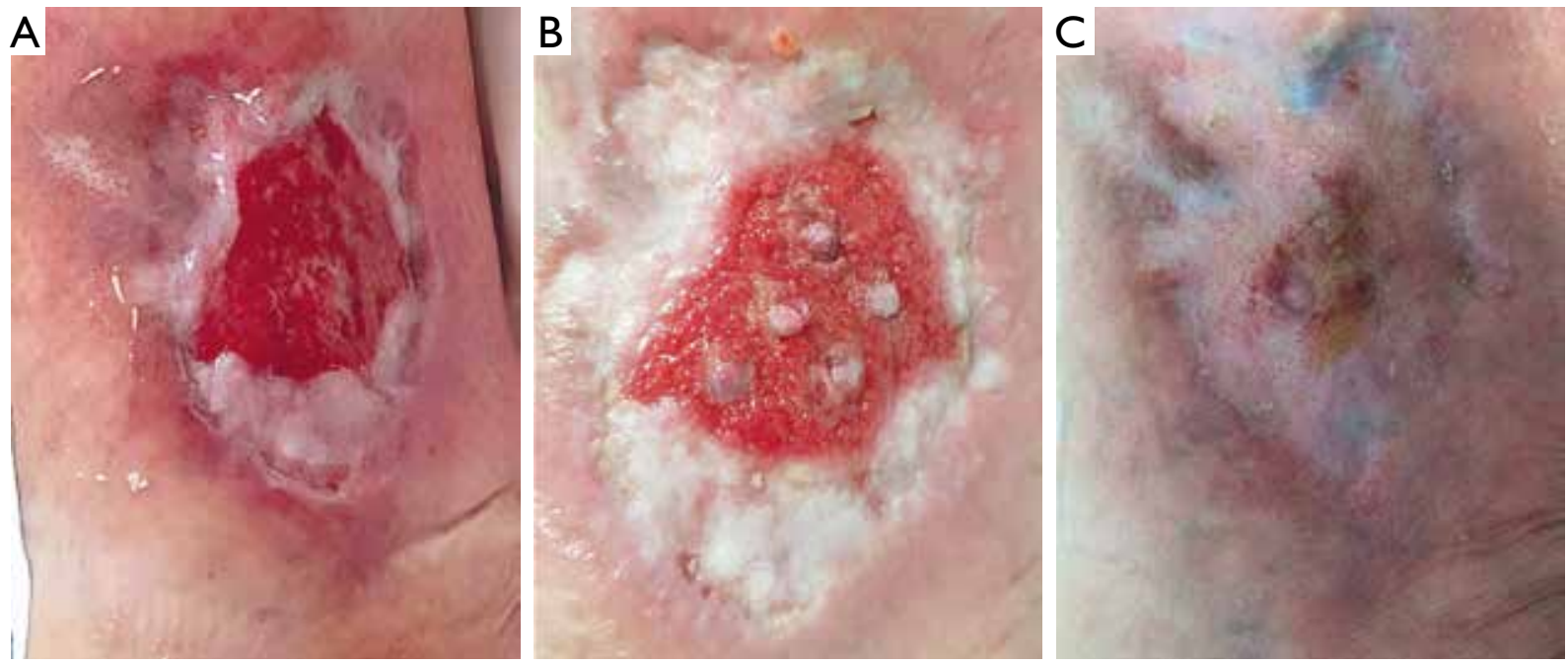

Figure 2. Patient number I wound status: $\mathbf{A}$ - before the procedure at day $0, \mathbf{B}$ - at day $7, \mathbf{C}$ - at day 30

Rycina 2. Stan rany u pacjenta $\mathrm{nr}$ I: A - przed zabiegiem (dzień 0), B - w dniu 7., C - w dniu 30. od zabiegu 

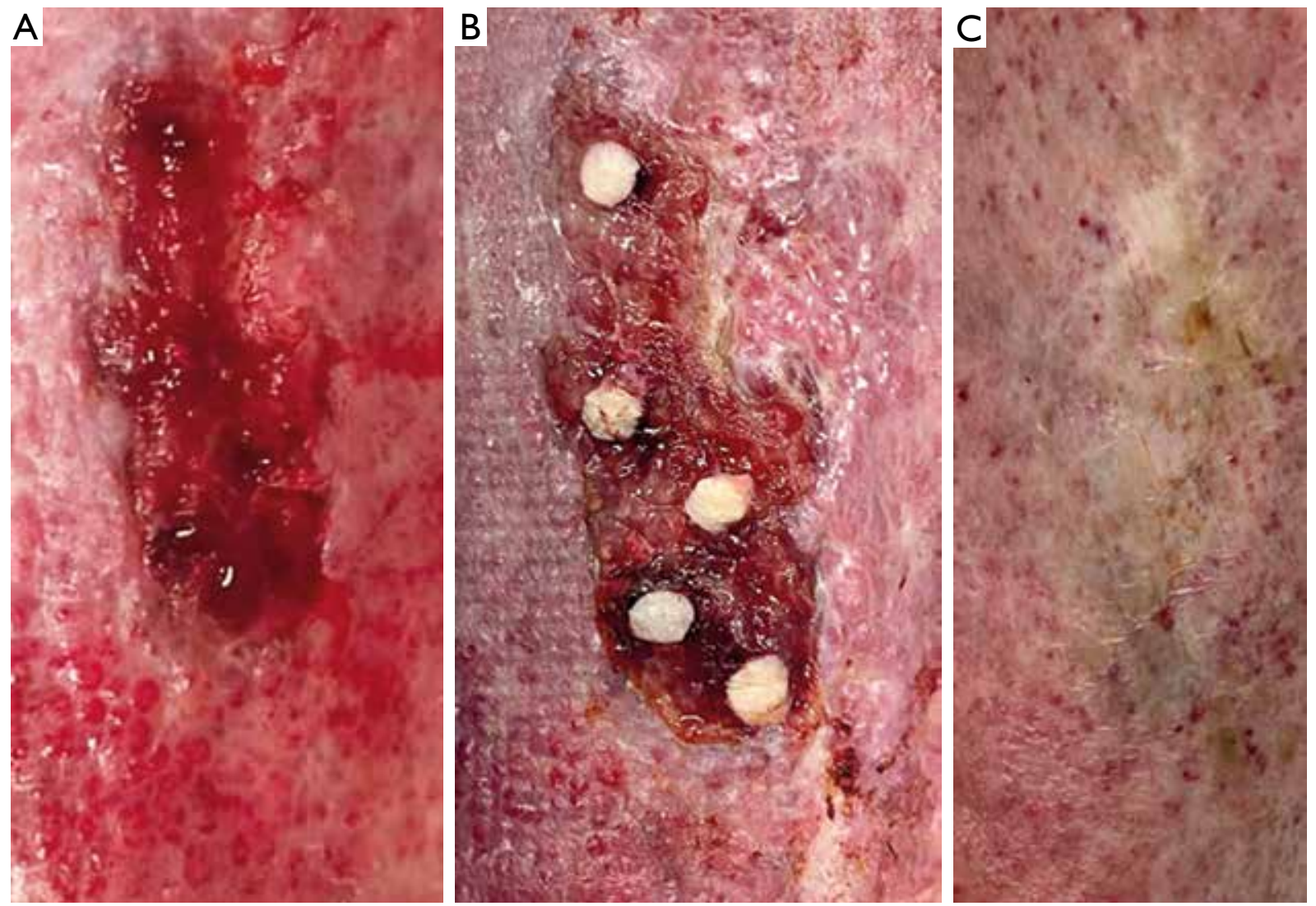

Figure 3. Patient number 4 wound status: $\mathbf{A}$ - before the procedure at day $0, \mathbf{B}-$ at day $7, \mathbf{C}$ - at day 30

Rycina 3. Stan rany u pacjenta nr 4: A - przed zabiegiem (dzień 0), B - w dniu 7., C - w dniu 30. od zabiegu

tion, hematoma formation, prolonged healing of both recipient and donor sites [30]. The risk is yet similar to the one when performing a skin biopsy, which is relatively low, as the puncturing is around $4-5 \mathrm{~mm}$ in diameter. Aware of those complications, we maintain sterile conditions and haemostasis during the procedure. Improper transplantation or incorrectly applied dressing may also lead to the fact that transplant will not be accepted, hence the immobilization of places where transplants have been located is so important after the procedure [31]. The first days after skin transplantation and proper management will have a major influence on the wound healing process. This is why we stress the importance of using compression therapy throughout the whole process. It is essential to treat the underlying condition to maintain proper blood supply to the skin. No compression therapy was used in the studies that have already been published, which could have prolonged the healing time of the ulcer $[25,26]$.

Undoubtedly, randomised controlled trials on a bigger study sample would be advised and could contribute to confirmation of our initial results. We suggest gathering 3 study groups, to get statistically significant comparison of treatment outcomes after the micrografting procedure, treatment with wound korzystaniu testu $\chi^{2}$ Pearsona wyniosła 0,322 (tj. była większa od 0,05), przyjmujemy, że nasze wyniki są znamienne statystycznie, a obserwowane różnice nie są przypadkowe. Obserwowany rozkład nie jest więc taki sam jak u pacjentów z przewlekłymi owrzodzeniami, którzy otrzymują leczenie zachowawcze.

\section{OMÓWIENIE}

Doświadczenia w leczeniu pacjentów z owrzodzeniami żylnymi w Klinice Dermatologii pozwalają nam przypuszczać, że mikroprzeszczepy wykonywane przy zastosowaniu sztancy dermatologicznej mają bardzo duży potencjał przyspieszania procesu epitelializacji owrzodzeń żylnych. W porównaniu z zabiegiem wykonywanym za pomocą systemu próżniowego i dermatomu jest to metoda tańsza i prostsza. Koszt jednego zabiegu wynosi około 10 euro i obejmuje dwie sztance dermatologiczne i zestaw do zakładania szwów. Dla porównania jeden zabieg przeszczepu skóry przy zastosowaniu dermatomu lub systemu próżniowego kosztuje około 1000 euro. Opisywana metoda może skracać czas gojenia się ran i przyspieszać epitelializację bez konieczności hospitalizacji pacjenta przed zabiegiem i po zabiegu. Może ponadto znamiennie obniżać koszty leczenia ran u pacjentów z przewlekłymi owrzodzeniami, 
dressings only and patients subjected to more conventional skin transplantation procedures, such as split-skin grafting.

\section{CONCLUSIONS}

Skin micrografting with a biopsy punch can be an effective and cost-effective alternative for boosting epithelialization of granulated leg ulcers.

\section{ACKNOWLEDGMENTS}

The patients in this manuscript have given written informed consent to publication of their case details.

\section{CONFLICT OF INTEREST}

The authors declare no conflict of interest. które są coraz większym problemem dla lekarzy w całej Europie, zwłaszcza na oddziałach dermatologicznych.

Podobnie jak w przypadku każdej metody leczenia, która powoduje naruszenie ciągłości tkanek, opisana technika wiąże się z pewnym ryzykiem krwotoku, zakażenia, powstawania krwiaków oraz przedłużonego gojenia zarówno w miejscu biorczym, jak i dawczym [30]. Ryzyko jest jednak podobne jak przy wykonywaniu biopsji skóry. Jest ono stosunkowo niskie, gdyż nakłucie ma średnicę zaledwie około 4-5 mm. Aby uniknąć powikłań, zalecane jest jednak utrzymywanie sterylnych warunków zabiegu oraz hemostazy. Nieprawidłowo wykonany przeszczep lub niewłaściwie założony opatrunek może prowadzić do odrzucenia przeszczepu. Dlatego tak istotne jest unieruchomienie miejsc biorczych przeszczepów po zabiegu [31]. Pierwsze dni po przeszczepie skóry oraz prawidłowe postępowanie z pacjentem mają kluczowe znaczenie dla przebiegu procesu gojenia rany. Z tego względu podkreślamy znaczenie kompresjoterapii w całym procesie leczenia. Istotne jest leczenie choroby podstawowej, aby utrzymać prawidłowe ukrwienie skóry. W pracach dostępnych w piśmiennictwie nie stosowano terapii uciskowej, co mogło wydłużać czas gojenia owrzodzenia $[25,26]$.

Niewątpliwie korzystne byłoby przeprowadzenie badań w schemacie $\mathrm{z}$ randomizacją i grupą kontrolną oraz udziałem większej liczby pacjentów. Na tej podstawie można byłoby zweryfikować wstępne wyniki przedstawione $\mathrm{w}$ niniejszej pracy. Zdaniem autorów warto byłoby przeprowadzić badanie obejmujące 3 grupy pacjentów, aby uzyskać statystycznie istotne porównanie wyników leczenia przy zastosowaniu mikroprzeszczepów skóry, wyłącznie opatrunków na ranę oraz bardziej konwencjonalnych metod przeszczepu (np. przeszczepu skóry niepełnej grubości).

\section{WNIOSKI}

Mikroprzeszczep skóry wykonywany za pomocą sztancy biopsyjnej może być skuteczną i efektywną kosztowo alternatywą w przypadkach wymagających przyspieszenia epitelializacji ziarninujących owrzodzeń w obrębie kończyn dolnych.

\section{PODZIEZKOWANIA}

Pacjenci opisani w pracy wyrazili pisemną świadomą zgodę na opublikowanie informacji dotyczących swoich przypadków.

\section{KONFLIKT INTERESÓW}

Autorzy nie zgłaszają konfliktu interesów. 


\section{References}

\section{Piśmiennictwo}

1. Jawien A., Grzela T., Ochwatt A.: Prevalence of chronic venous insufficiency in men and women in Poland: multicentre cross-sectional study in 40,095 patients. Phlebology 2003, 18, 110-122.

2. Steins A., Jünger M.: Physical therapy in patients with chronic venous insufficiency. Phlebologie 2000, 29, 48-53.

3. Felty C.L., Rooke T.W.: Compression therapy for chronic venous insufficiency. Semin Vasc Surg 2005; 18: 36-40.

4. Vaidyanathan S.: Principles of treatment of chronic venous insufficiency. In: Chronic Venous Disorders of the Lower Limbs: A Surgical Approach. S. Vaidyanathan, R.R. Menon, P. Jacob, B. John. Springer India 2015, 129-138.

5. Partsch H.: Compression therapy: clinical and experimental evidence. Ann Vasc Dis 2012, 5, 416-422.

6. Atkin L., Bućko Z., Montero E.C., Cutting K., Moffatt C., Probst A., et al.: Implementing TIMERS: the race against hard-to-heal wounds. J Wound Care 2019, 23 (Suppl. 3a): S1-S50.

7. Halim A.S., Khoo T.L., Saad A.Z.: Wound bed preparation from a clinical perspective. Indian J Plastic Surg 2012, 45, 193-202.

8. Schultz G.S., Barillo D.J., Mozingo D.W., Chin G.A.; Wound Bed Advisory Board Members.: Wound bed preparation and a brief history of TIME. Int Wound J 2014, 1, 19-32.

9. Schultz G.S., Sibbald R.G., Falanga V., Ayello E.A., Dowsett C., Harding K., et al.: Wound bed preparation: a systematic approach to wound management. Wound Repair Regen 2003, 11 Suppl 1, S1-S28.

10. Leaper D.J., Schultz G., Carville K., Fletcher J., Swanson T., Drake R.: Extending the TIME concept: what have we learned in the past 10 years? Int Wound J 2012, 9 Suppl 2, 1-19.

11. Pascarella L., Shortell C.K.: Medical management of venous ulcers. Semin Vasc Surg 2015, 28, 21-28.

12. White J.V., Ryjewski C.: Chronic venous insufficiency. Perspect Vasc Surg Endovasc Ther 2005, 17, 319-327.

13. Carpentier P.H., Maricq H.R., Biro C., Ponçot-Makinen C.O., Franco A.: Prevalence, risk factors, and clinical patterns of chronic venous disorders of lower limbs: a population-based study in France. J Vasc Surg 2004, 40, 650-659.

14. Carpentier P.H.: Epidemiology and physiopathology of chronic venous leg diseases. Rev Prat 2000, 50, 1176-1181.

15. Partsch H.: Varicose veins and chronic venous insufficiency. VASA 2009, 38, 293-301.

16. Graham I.D., Harrison M.B., Nelson E.A., Lorimer K., Fisher A.: Prevalence of lower-limb ulceration: a systematic review of prevalence studies. Adv Skin Wound Care 2003, 16, 305-316.

17. Lyons O.T., Saha P., Smith A.: Redox dysregulation in the pathogenesis of chronic venous ulceration. Free Radical Biol Med 2020, 149, 23-29.

18. Kadam D.: Novel expansion techniques for skin grafts. Indian J Plast Surg 2016, 49, 5-15.

19. Smith O.J., Edmondson S.J., Bystrzonowski N., Hachach-Haram N., Kanapathy M., Richards T., et al.: The CelluTome epidermal graft-harvesting system: a patient-reported outcome measure and cost evaluation study. Int Wound J 2017, 14, 555-560.

20. McBride C.A., Kempf M., Kimble R.M., Stockton K.: Variability in split-thickness skin graft depth when using an air-powered dermatome: a paediatric cohort study. Burns 2017, 43, 1552-1560.

21. Vinceneux Talvande B., Carvalho Lallement P., Safa G., Tollhupp J.J., Lembelembe J.P., Blaise S., et al.: Use of Cellutome for the healing of venous or mixed ulcers. Int Wound J 2018, 15, 993-999.

22. Edmondson S.J., Smith O., Bystrzonowski N., Hachach-Haram N., Kanapathy M., Twyman L., et al.: To cellutome or not to cellutome? A patient reported outcome measure and cost evaluation study. Int J Surg 2016, 14, 555-560.

23. Hachach-Haram N., Bystrzonowski N., Kanapathy M., Smith O., Harding K., Mosahebi A., et al.: A prospective, multicentre study on the use of epidermal grafts to optimise outpatient wound management. Int Wound J 2017, 14, 241-249.

24. Serena T.E.: Use of epidermal grafts in wounds: a review of an automated epidermal harvesting system. J Wound Care 2015, 24 (4 Suppl), 30-34.

25. Nordström A., Hansson C.: Punch-grafting to enhance healing and to reduce pain in complicated leg and foot ulcers. Acta Derm Venereol 2008, 88, 389-391.

26. Fernandez J.W., Akamie R.S., Casagrande E.C.: Punch grafts to treat lower limb intractable sores. Rev Col Bras Cir 2017, 44, 659-664.

27. Hjerppe A., Sane M., Huhtala H., Vaalasti A.: Pinch grafting of chronic leg ulcers: a retrospective analysis of 104 patients with 169 ulcers. J Wound Care 2010, 19, 37-40.

28. Hakkarainen T., Koivuniemi R., Kosonen M., Escobedo-Lucea C., Sanz-Garcia A., Vuola J., et al.: Nanofibrillar cellulose wound dressing in skin graft donor site treatment. J Control Release 2016, 244, 292-301.

29. Demirtas Y., Yagmur C., Soylemez F., Ozturk N., Demir A.: Management of split-thickness skin graft donor site: a prospective clinical trial for comparison of five different dressing materials. Burns 2010, 36, 999-1005.

30. Abhishek K., Khunger N.: Complications of skin biopsy. J Cutan Aesthet Surg 2015, 8, 239-241.

31. Golpanian S., Kassira W.: Full-thickness skin graft. In: Operative Dictations in Plastic and Reconstructive Surgery. T.A. Tran, Z. Panthaki, J.J. Hoballah, S.R. Thaller. Springer, Switzerland 2016, 199-201.

Received: 20.04 .2021

Accepted: 5.09.2021

Otrzymano: 20.04.2021 r.

Zaakceptowano: $5.09 .2021 \mathrm{r}$

How to cite this article

Nowak M.A., Mehrholz D.M., Barańska-Rybak W.: Assessment of the effect of punch full-thickness skin grafting on wound epithelialization. Dermatol Rev/Przegl Dermatol 2021, 108, 266-274. DOI: https://doi.org/10.5114/dr.2021.110785. 